\title{
Pola Kuman dan Uji Kepekaan pada Pasien Community Acquired Pneumonia di RSUP Dr. M. Djamil Padang Tahun 2016
}

Narlis ${ }^{1}$, Ellyza Nasrul ${ }^{2}$, Efrida ${ }^{2}$

Abstrak

Community acquired pneumonia (CAP) merupakan infeksi yang paling sering menyebabkan sepsis dan dapat menimbulkan kematian. Pertimbangan pemilihan antimikroba yang tepat dan menghindari penggunaan yang berlebihan perlu dilakukan untuk mencegah terjadinya resistensi. Tujuan: Mengetahui pola kuman dan uji kepekaan pasien CAP di RSUP Dr. M. Djamil Padang. Metode: Ini merupakan penelitian deskriptif retrospektif terhadap 201 sampel sputum pasien CAP yang diperiksa kultur kemudian dilanjutkan dengan pewarnaan Gram dan uji biokimia untuk mengidentifikasi bakteri. Uji kepekaan antimikroba menggunakan metode difusi cakram. Penelitian dilakukan di Laboratorium Sentral RSUP Dr. M. Djamil Padang periode Januari 2016 hingga Desember 2016. Data ditampilkan dalam bentuk tabel distribusi frekuensi. Hasil: Mikroorganisme yang ditemukan adalah Klebsiella pneumonia (55,23\%), Staphylococcus aureus (25,87\%), Streptococcus pneumonia (7,96\%), Pseudomonas aeruginosa (5,97\%), Staphylococcus epidermidis (2,9\%), Acinetobacter baumani (1,99\%), Proteus vulgaris (0,49\%). Antimikroba yang paling sensitif adalah Meropenem (78,7\%), sedangkan antimikroba resisten dengan persentase tertinggi adalah Ampisilin (90\%), Amoksisilin (89,4\%), Eritromisin (73,5\%), Amoksisilin + Klavulanat (64,6\%), dan Kloramfenikol $(61,7 \%)$. Mikroorganisme yang paling banyak ditemukan adalah Klebsiella pneumonia (55,23\%). Meropenem merupakan antimikroba sensitif dengan persentase paling tinggi $(78,7 \%)$ sedangkan antimikroba resisten dengan persentase paling tinggi adalah ampisilin (90\%). Simpulan: Meropenem adalah antimikroba paling sensitif dan ampisilin adalah paling resisten dalam penelitian ini.

Kata kunci: community acquired pneumonia, pola kuman, uji kepekaan

\section{Abstract}

Community acquired pneumonia (CAP) is the most common cause of severe sepsis and the leading cause of death. Consideration of appropriate antimicrobial selection and avoid overuse is necessary to prevent resistance. Objectives: To evaluated microbial profile and antimicrobial sensitivity pattern in Dr. M. Djamil Hospital Padang. Methods: This research was descriptive retrospective study to 201 sputum samples of CAP patient that culture examination, then Gram staining and biochemical test for identification microorganism in the Central Laboratory of Dr. M. Djamil Hospital Padang in period January 2016 until December 2016. Antimicrobial sensitivity test were performed using disc diffusion method. Data was displayed in frequency distribution table. Results: Microorganism were found Klebsiella pneumonia (55,23\%), Staphylococcus aureus (25,87\%), Streptococcus pneumonia (7,96\%), Pseudomonas aeruginosa (5,97\%), Staphylococcus epidermidis (2,49\%), Acinetobacter baumani (1,99\%), Proteus vulgaris $(0,49 \%)$. The most sensitive antimicrobial in this study was Meropenem (78.7\%). The highest resistent antimicrobial was Ampicilin (90\%), Amoxicilin (89.4\%), Erythromycin (73.5\%), Amoxicilin + Clavulanat (64.6\%) and Chloramphenicol (61,7\%). The most microorganism was found Klebsiella pneumonia (55,23\%). The most sensitive antimicrobial in this study was Meropenem (78.7\%) and the most resistent antimicrobial was Ampicilin (90\%). Conclusions: Meropenem is the most sensitive and ampicilin is the resistent in this study.

Keywords: community acquired pneumonia, microbial profile pattern, antimicrobial sensitivity pattern 
Affiliasi penulis: 1. Puskesmas Taba Atas, Kabupaten Lebong 2. Bagian Patologi Klinik Fakultas Kedokteran Universitas Andalas Korespondensi: Narlis, Email: narlis0707@gmail.com Telp: 082170146067

\section{PENDAHULUAN}

Community acquired pneumonia (CAP) didefinisikan sebagai infeksi pada parenkim paru yang didapatkan dari rumah sakit, fasilitas rawatan atau sistem kesehatan lainnya. ${ }^{1}$ Community acquired pneumonia merupakan infeksi yang paling sering menyebabkan sepsis dan dapat menimbulkan kematian. Kematian dan perburukan pasien CAP berhubungan dengan imunitas tubuh, patogenitas kuman, dan terapi antimikroba. ${ }^{2}$

Angka mortalitas pasien CAP meningkat karena kuman yang menginfeksi merupakan kuman patogen yang resisten terhadap terapi antimikroba yang umum diberikan. Pertimbangan pemilihan antimikroba yang tepat dan menghindari penggunaan yang berlebihan penting untuk dilakukan. Klinisi seharusnya mempertimbangkan pola resistensi kuman dalam memberikan terapi awal antimikroba di klinik atau rumah sakit tempat bertugas, karena etiologi CAP dapat berbeda-beda antar daerah dan Negara. ${ }^{3}$

Penelitian mortalitas CAP di Indonesia terhadap pasien rawat inap paru di RSUD Dr. Zainoel Abidin Banda Aceh didapatkan hasil 35\% meninggal akibat CAP. ${ }^{4}$ Penelitian yang dilakukan di instalasi rawat inap Rumah Sakit Umum Pusat H. Adam Malik Medan Periode Oktober hingga Desember 2010 dan periode Januari hingga Maret 2011 didapatkan pasien yang meninggal akibat CAP sebanyak 33,3\%. ${ }^{5}$

Penelitian pola kuman dan uji kepekaan terhadap pasien CAP di Laboratorium Mikrobiologi Rumah Sakit Persahabatan Jakarta mendapatkan kuman penyebab CAP didominasi oleh kuman Gram negatif yaitu Klebsiella pneumoniae, Acinetobacter baumanii, dan Escherichia coli, meskipun demikian kuman Gram positif Streptoccocus viridans banyak juga ditemukan. Jenis kuman yang terbanyak ditemukan adalah Klebsiella pneumoniae (34\%), sedangkan kuman lainnya seperti Staphylococcus epidermidis, Enterobacter, Escherichia cloacae, dan Klebsiella oxytica memiliki angka insiden yang rendah. Lima besar jenis antimikroba resisten yang ditemukan pada penelitian ini yaitu Sefazolin (50\%), Amoksisilin + Klavulanat (37,8\%), Seftriakson (36,4\%), Ampisilin + Sulbaktam (33,3\%), Kloramfenikol (32,4\%). Jenis antimikroba yang masih sensitif $100 \%$ pada pasien CAP di rumah sakit Persahabatan adalah Imipenem dan Piperasilin. ${ }^{6}$

Berdasarkan latar belakang di atas, maka peneliti tertarik untuk melakukan penelitian pola kuman dan uji kepekaan pada pasien CAP di RSUP Dr. M. Djamil Padang tahun 2016. Penelitian ini bertujuan untuk mengetahui pola kuman dan hasil uji kepekaan isolat sputum pasien CAP di RSUP Dr. M. Djamil Padang tahun 2016.

\section{METODE}

Penelitian ini adalah penelitian deskriptif retrospektif yang dilakukan di Laboratorium Sentral RSUP Dr. M. Djamil Padang mulai Januari hingga Desember 2016. Subjek penelitian adalah kultur positif sampel pasien CAP.

Sampel yang datang ke Laboratorium Sentral RSUP Dr. M. Djamil padang dibuat sediaan dan diwarnai dengan pewarnaan Gram, kemudian dilakukan penanaman pada media kultur agar darah. Media agar diinkubasi pada suhu 33-37ㅇ C selama 18-24 jam dan diidentifikasi adanya pertumbuhan koloni, kemudian dilanjutkan dengan pemeriksaan uji biokimia antara lain Triple Sugar Iron Agar (TSIA), sulfide indole motility agar (SIM), dan hidrogen peroksida $3 \%$. Mikroorganisme diidentifikasi berdasarkan morfologi koloni kuman, sifat Gram dan uji biokimia. ${ }^{7}$

Uji kepekaan antibiotik dilakukan menggunakan metode Kirby-Bauer (disc diffusion technique). Bakteri dari kultur disuspensikan dalam larutan normal salin sampai kepekatannya sama dengan larutan standar 0,5 McFarland. Suspensi diinokulasikan secara merata pada agar Muller Hinton. Cakram antibiotik diletakkan pada bagian atas agar dengan jarak setiap cakram sebesar $30 \mathrm{~mm}$. Medium agar tersebut diinkubasi pada suhu $35^{\circ} \mathrm{C}$ selama 18 jam. Hasil uji kepekaan bakteri merupakan nilai hambat bakteri tersebut terhadap berbagai jenis antibiotik dengan cara mengukur area jernih di sekitar antibiotik. $^{8}$ 
Hasil uji kepekaan bakteri merupakan nilai hambat bakteri tersebut terhadap berbagai jenis antibiotik. Hasil uji kepekaan dikategorikan sebagai sensitif, intermediet, dan resisten dengan cara mengukur area jernih di sekitar antibiotik. Data diolah secara manual dan ditampilkan dalam bentuk tabel distribusi frekuensi.

\section{HASIL}

Penelitian ini melibatkan 201 pasien yang menderita CAP dan diperiksa sampel sputumnya untuk mengidentifikasi patogen penyebab dan uji kepekaan antimikroba pada periode Januari 2016 hingga Desember 2016.

Mikroorganisme yang ditemukan pada pasien CAP di RSUP Dr. M. Djamil Padang periode Januari 2016 hingga Desember 2016 adalah Klebsiella pneumonia, Staphylococcus aureus, Streptococcus pneumonia, Pseudomonas aeruginosa, Staphylococcus epidermidis, Acinetobacter baumani, Proteus vulgaris. Mikroorganisme yang paling banyak ditemukan pada pasien tersebut adalah Klebsiella pneumonia sebanyak 111 kasus (55,23\%) sedangkan yang terbanyak kedua adalah Staphylococcus aureus sebanyak 52 kasus (25,87\%) pada Tabel 1.

Berdasarkan uji kepekaan yang dilakukan terhadap mikrorganisme yang ditemukan didapatkan antimikroba yang paling sensitif adalah meropenem (78,7\%), sedangkan hasil 5 besar yang resisten antara Iain Ampisilin (90\%), Amoksisilin (89,4\%), Eritromisin (73,5\%), Amoksisilin + Klavulanat (64,6\%), dan Kloramfenikol $(61,7 \%)$ pada Tabel 2.

Tabel 1. Distribusi frekuensi kuman penyebab CAP di RSUP Dr. M. Djamil Padang periode Januari hingga Desember 2016

\begin{tabular}{lll}
\hline Jenis Mikroorganisme & $\mathbf{f}$ & $\%$ \\
\hline Klebsiella pneumonia & 111 & 55,23 \\
Staphylococcus aureus & 52 & 25,87 \\
Streptococcus pneumonia & 16 & 7,96 \\
Pseudomonas aeruginosa & 12 & 5,97 \\
Staphylococcus epidermidis & 5 & 2,49 \\
Acinetobacter baumani & 4 & 1,99 \\
Proteus vulgaris & 1 & 0,49 \\
\hline
\end{tabular}

Tabel 2. Distribusi frekuensi uji kepekaan pasien CAP di RSUP Dr. M Djamil Padang periode Januari hingga Desember 2016

\begin{tabular}{llll}
\hline & S (\%) & I (\%) & R (\%) \\
\hline Ampisilin & 7,5 & 2,5 & 90 \\
Amoksisilin & 9,1 & 1,5 & 89,4 \\
Eritromisin & 16,3 & 10,2 & 73,5 \\
Amoksisilin + Klavulanat & 28,6 & 6,8 & 64,6 \\
Seftriakson & 30,1 & 13,5 & 56,4 \\
Kloramfenikol & 34,8 & 3,5 & 61,7 \\
Sefotaksim & 37,9 & 13,5 & 48,6 \\
Seftrazidin & 43,5 & 14,6 & 41,9 \\
Siprofloksasin & 44,9 & 3,6 & 51,5 \\
Gentamisin & 54,1 & 1,5 & 44,4 \\
Levofloksasin & 55,9 & 6,2 & 37,9 \\
Meropenem & 78,7 & 2,6 & 18,7 \\
\hline
\end{tabular}

\section{PEMBAHASAN}

Hasil penelitian yang dilakukan di Laboratorium Mikrobiologi Rumah Sakit Persahabatan Jakarta sama dengan penelitian ini dalam mendapatkan hasil mikroorganisme yang terbanyak yaitu Klebsiella pneumoniae (34\%). ${ }^{6}$ Hasil penelitian yang dilakukan di Rumah Sakit Mangalore Coastal Karnataka India berbeda dengan penelitian ini yang mendapatkan hasil mikroorganisme paling banyak adalah Streptococcus pneumonia (31\%) sedangkan pada penelitian ini Streptococcus pneumonia merupakan mikroorganisme kedua terbanyak setelah Klebsiella pneumoniae. $^{9}$

Penelitian yang dilakukan di Laboratorium Mikrobiologi Dhaka Medical Bangladesh juga mendapatkan hasil yang berbeda dengan penelitian ini yaitu mendapatkan mikroorganisme terbanyak adalah Streptococcus pneumonia (19,05\%) sedangkan Klebsiella pneumonia (13,33\%) merupakan mikroorganisme kedua terbanyak. Perbedaan hasil pola kuman disebabkan oleh faktor penggunaan antimikroba, kesadaran menjaga kesehatan, dan perubahan harapan hidup manusia. ${ }^{10}$ Hasil penelitian uji kepekaan di RSUP Dr. M. Djamil Padang periode Januari 2016 hingga Desember 2016 berbeda dengan hasil uji kepekaan yang dilakukan di Laboratorium Mikrobiologi Rumah Sakit Persahabatan Jakarta yang mendapatkan jenis 
antimikroba yang paling sensitif adalah Imipenem dan Piperasilin (100\%). ${ }^{6}$ Hasil penelitian yang dilakukan di RSUP Dr. M. Djamil Padang tidak ditemukan jenis antimikroba yang sensitif $100 \%$.

Hasil penelitian uji kepekaan yang termasuk antimikroba resisten terbesar di Laboratorium Mikrobiologi Rumah Sakit Persahabatan Jakarta ada beberapa yang sama dengan hasil penelitian yang dilakukan oleh peneliti di laboratorium sentral RSUP Dr. M. Djamil Padang yaitu Amoksisilin + Klavulanat dan Kloramfenikol. Antimikroba Amoksisilin+ Klavulanat dan Kloramfenikol walaupun merupakan antimikroba resisten yang terbesar, namun persentase kejadiannya lebih banyak di laboratorium sentral RSUP Dr. M. Djamil Padang yaitu Amoksisilin + Klavulanat $(64,6 \%$ dibandingkan $37,8 \%)$ dan Kloramfenikol (61,7\% dibandingkan 32,4\%).

Mikroorganisme penyebab CAP dan kepekaan terhadap antimikroba antara satu daerah dengan daerah lainnya dapat berbeda-beda. Mikroorganisme penyebab CAP dan kepekaan terhadap antimikroba dalam satu daerah juga dapat berbeda pada periode waktu yang berbeda.

Resistensi bakteri terhadap obat antibiotik kemungkinan besar disebabkan penggunaan yang luas dari antibiotik tersebut dengan dosis dan lama pemberian yang tidak rasional dan tidak terkontrol. Perkembangan resistensi bakteri terhadap antibiotika juga dipengaruhi oleh intensitas pemaparan. Penggunaan antibiotik yang terkendali sangat penting untuk mencegah resistensi bakteri.

\section{SIMPULAN}

Mikroorganisme yang paling banyak ditemukan sebagai penyebab CAP di RSUP Dr. M. Djamil Padang adalah Klebsiella pneumonia. Meropenem merupakan antimikroba sensitif dengan persentase paling tinggi, sedangkan antimikroba resisten paling tinggi adalah ampisilin.

\section{UCAPAN TERIMAKASIH}

Terimakasih yang sebesar-besarnya penulis ucapkan kepada RSUP Dr. M. Djamil Padang yang telah membantu dan memfasilitasi penelitian ini.

\section{DAFTAR PUSTAKA}

1. Watkins RR, Lemonovich TL. Diagnosis and management of community acquired pneumonia in adults. American Academy of Famil Physician, Am Fam Physician. 2011;83(11):1299-1306.

2. Waterer GW, Rello J, Wunderink RG. Management of community acquired pneumonia in adults; concise clinical review. Respiratory Critical Care Medicine. 2011;183:157-64.

3. Liapikou A, Tores A. Current treatment of community-acquired pneumonia. Expert Opinion Pharmacother. Informa Health Care. 2013;14(10): 1319-32.

4. Andayani N. Tingkat mortalitas dan prognosis pasien pneumonia komunitas dengan sistem skoring curb-65 di Ruang Rawat Inap Paru RSUD Dr. Zainoel Abidin Banda Aceh. Journal Kedokteran Syiah Kuala. 2014;1:14-9.

5. Nurul H. Korelasi drug related problems (DRP) pengguna antibiotika terhadap prognosis pasien pneumonia di Instalasi Rawat Inap Rumah Sakit Umum Pusat H. Adam Malik Medan periode Oktober-Desember 2010 dan periode JanuariMaret 2011. Jurnal Universitas Sumatra Utara. $2011 ; 3(2): 41-5$.

6. Faisal F, Burhan E, Aniwidyaningsih W, Kekalih A. Penilaian respon pengobatan empiris pada pasien rawat inap dengan pneumonia komunitas. Journal respirology. 2014;34:60-70.

7. Collins $\mathrm{CH}$, Lyne PM, Grange JM, Falkinham III J.O. Cultural methods. Collins and Lyne's microbiological methods. Eighth edition. London: Arnold; 2004.hlm.81-8. 
8. Ortez JH. Disk Diffusion Testing. Dalam: Coyle $\mathrm{MB}$, editor (penyunting). Manual of antimicrobial susceptibility testing. Washington: American Society for Microbiology. 2005.hlm. 25-100.

9. Acharya VK, Padyana M, Unnikkrishnan B, Archarya P, Juneja DJ. Microbiological profile and drug sensitivity pattern among community acquired pneumonia patients in tertiary care centre in Mangalore, Coastal Karnataka India. Journal of Clinical and Diagnostic Research. 2014; 8(6):1-6.

10. Akter S, Shamsuzzaman SM, Jahan F. Community acquired bacterial pneumonia: aetiology, laboratory detection, and antibiotic susceptibility pattern. Malaysian Journal of Pathology. 2014;36(2):97-103 